\title{
ASSESSMENT OF THE KNOWLEDGE MANAGEMENT PROJECT AT CROATIAN POLYTECHNICS
}

\author{
Gordana Dukić, Goran Kozina, Marin Milković
}

Original scientific paper The main aim of this paper was to establish to what extent the knowledge management project has become a reality at Croatian polytechnics, and how far polytechnics have fulfilled their task. The analysis was based on the perceptions of polytechnic students. In the survey encompassing 818 respondents the emphasis was on the assessment of knowledge gained, and the process of knowledge transfer. The research results have indicated that there are several areas in which additional efforts must be undertaken in order to fully implement the knowledge management project. On the one hand, the obtained results can be used as a guideline for eliminating the noticed deficiencies; on the other, they can be the foundation for formulating future development strategies of Croatian polytechnics. The research also has a wider significance, insofar as the instrument that was developed can be applied to analyse the performance of any higher education system.

Keywords: development strategy; knowledge management; polytechnics; project

Ocjena projekta upravljanja znanjem na hrvatskim veleučilištima

Izvorni znanstveni članak

Glavni je cilj ovog rada bio utvrditi u kojoj je mjeri projekt upravljanja znanjem zaživio na hrvatskim veleučilištima, te koliko su, u tom smislu, veleučilišta ispunila svoju zadaću. Analiza navedene problematike temeljila se na percepciji veleučilišnih studenata. U anketi, koja je obuhvatila 818 studenata, naglasak je bio stavljen na ocjenu stečenih znanja, odnosno procesa njihovog prenošenja. Rezultati istraživanja pokazali su da postoje brojna područja u kojima je potrebno učiniti dodatne napore kako bi se projekt upravljanja znanjem u potpunosti realizirao. Dobiveni rezultati mogu poslužiti ne samo kao vodilja za otklanjanje uočenih nedostataka, već također predstavljaju temelj za kreiranje budućih strategija razvoja hrvatskih veleučilišta. Istraživanje ima i šire značenje, budući da se instrument kojeg smo razvili može primijeniti sa svrhom analize uspješnosti funkcioniranja bilo kojeg visokoobrazovnog sustava.

Ključne riječi: projekt; strategija razvoja; upravljanje znanjem; veleučilišta

\section{Introduction}

Accurate, relevant and timely information, as well as adequate knowledge, are prerequisites for the achievement of objectives in any organization. More than ever before, today's organizations need to be able to take advantage of the information and knowledge they possess in order to improve their performance and efficiency. Otherwise, they will be unable to respond to challenges they are faced with on a daily basis. Knowledge management is a tool that can help organizations to better utilize information, and, perhaps more importantly, different kinds of knowledge. Knowledge management is therefore one of the major sources of competitive advantage. All this indicates that efficient knowledge management is the key to success of any organization.

In the context of knowledge management, a special place belongs to institutions in the higher education system. They are primarily the origin of human capital and resources, which is absolutely indispensable for normal functioning of the entire community. Due to technological advances there is the continuously growing demand for employees with specific knowledge and skills; it is the task of the higher education system to meet such needs of the business sector and society in general. In addition, institutions of higher education are centres of research activities. They create knowledge, but are also responsible for turning out research and scientific personnel. If the higher education system failed to fulfil its tasks the consequences would be both far-reaching and highly detrimental.

The concept of knowledge management is not easy to define. According to Gupta, Sharma and Hsu [1] knowledge management is an emerging, interdisciplinary business model dealing with all aspects of knowledge within the context of the firm, including knowledge creation, codification, sharing, and using these activities to promote learning and innovation. In Groff and Jones [2] knowledge management is taken as the tools, techniques, and strategies to retain, analyse, organize, improve, and share business expertise. Tiwana [3] defined knowledge management as management of organizational knowledge for creating business value and generating a competitive advantage. In the above definitions knowledge management is viewed primarily as a business philosophy. Such an approach is understandable, given that it was the business sector which initiated and developed knowledge management, but also implemented it more than other sectors. On the other hand, knowledge management projects have not yet been properly validated in higher education institutions. Metcalfe [4] argues that in contrast to the business sector, the application of knowledge management in higher education has been only partially examined.

To bring forward its wider, more universal meaning, we will present several other approaches to the concept of knowledge management. Uriarte [5] believes that knowledge management can be seen as the conversion of tacit knowledge into explicit knowledge and sharing it within the organization. If we want to be more specific and accurate, knowledge management can, according to Uriarte, be defined as the process through which organizations generate value from their intellectual and knowledge-based assets. Pan, Newell, Huang and Galliers [6] state that knowledge management involves a range of processes, including creating, sharing, integrating, storing, 
and reusing knowledge. According to Prat [7] knowledge management is a multidisciplinary subject, with contributions from such disciplines as information systems and information technology, strategic management, organizational theory, human-resource management, education science, psychology, cognitive science, and artificial intelligence. Thus, in order to make full use of all these disciplines and their contributions, one needs to take a multidisciplinary approach when exploring and implementing knowledge management.

The objective of our research was to establish to what extent the knowledge management project has become a reality at Croatian polytechnics, and particularly, how far polytechnics have fulfilled their task of distributing, or transferring knowledge to students. The following hypotheses were formulated in this study:

- Knowledge management is not implemented effectively in Croatian polytechnics.

- Students identify specific areas for improvement.

- There are significant differences in students' attitudes with respect to their socio-demographic characteristics.

To better understand the purpose and role of polytechnics within the Croatian higher education system, it should be noted that polytechnics are meant to provide students with adequate level of knowledge and skills, which will enable them to pursue a professional occupation. For this reason, Croatian polytechnics are offering professional studies whose aim is to train students in a way that will enable them to start working immediately after acquiring their qualification.

\section{Review of the available literature that deals with knowledge management in higher education}

The possibilities of using knowledge management in higher education began to be more seriously considered only about a decade ago. From that period we can single out the paper by Kidwell, Vander Linde and Johnson [8] which explores how knowledge management might be applied in higher education and whether higher education is ready to embrace it. The authors conclude that using knowledge management techniques and technologies in higher education is as vital as it is in the corporate sector. If done effectively, knowledge management can lead to better decision-making capabilities, reduce "product" development cycle time, improve academic and administrative services, and reduce costs. In that same year, in her conceptual article Rowley [9] also explores whether higher education is ready for knowledge management. The author identifies a number of existing facilities, systems or projects which contribute to knowledge management in higher education, such as libraries, electronic collections of learning materials, networks for e-mail communication, and management information systems which provide data on the student profile. She concludes that although knowledge-based organizations might seem to have the most to gain through knowledge management, effective knowledge management may require significant changes.

Based on the available literature it can be concluded that it was only in the past few years that researchers started to show a keener interest in studying different aspects of knowledge management in higher education. Thitithananon and Klaewthanong [10] seek to identify knowledge management concepts that relate to the implementation of knowledge management practices in higher education development, especially for Thailand's education system. The authors further discuss the benefits and problems of knowledge management practices and implications in different environments. Cranfield and Taylor [11] conducted a case study at seven higher education institutions within the United Kingdom in order to explore knowledge management practice and related perceptions. Among other things, the authors' findings indicate the following: higher education institutions are slowly beginning to prioritize knowledge management; to implement knowledge management within any organization, the correct culture needs to be cultivated; evidence of the benefits of explicitly adopting knowledge management principles needs to be clearly understood by individual researchers and academics, as well as the administrators; the taxonomy for the application of knowledge management within the higher education institutions context should be considered; the management structure of a university affects its ability to respond quickly to external influences and pressures; also, there is a correlation between the history of the institution and its ability to respond to the challenges. According to Dagli, Silman and Birol [12], in order to reach their objectives, universities utilize knowledge management systems in decision making, coordination, control, analysis, and visualization in an organization by collecting, processing, storing and disseminating the information. Chen, Huang and Cheng [13] focus on the issue of measuring knowledge management performance, which is bound to become increasingly important as time goes by. Their research measured knowledge management performance at a technical university using a competitive perspective. In this sense they developed an adequate methodology. The research by Penny, Dukić and Dukić [14] aimed to investigate information and communication technologies (ICT) usage among Scottish and Croatian students as a prerequisite for participating in knowledge management activities, and particularly in the process of knowledge transfer. The authors emphasize that knowledge management and ICT are closely related, since information and communication technologies hold the potential to improve knowledge and make it widely accessible. Laal [15] outlines the basic concepts of knowledge management in higher education institutions, and gives a summing up of previous scientific works. The author concludes that colleges and universities have significant opportunities to apply knowledge management practices to support every part of their mission, from education to research. The purpose of the article by Eftekharzade and Mohammadi [16] was to evaluate the capabilities of higher education to establish knowledge management. The authors investigate the situation at an Iranian university regarding organizational culture, information technology, organizational structure and human resources in order to establish a suitable model for knowledge management. 


\section{Sample and methods}

The research was conducted by means of a written questionnaire. The data were collected by taking a poll among students of six polytechnics from different regions of Croatia. The total number of respondents was 818 students. Their distribution in terms of gender, age group and professional area of studies is given in Tab. 1.

In our sample female students outnumbered their male counterparts. More than $80 \%$ of respondents were aged between 18 and 24 years. The largest number of surveyed students was enrolled in study programmes in the area of social studies, whereas programmes in the area of biotechnical studies accounted for the smallest number of students in the sample.

Table 1 Distribution of students in terms of gender, age group and area

\begin{tabular}{|c|c|c|}
\multicolumn{2}{|c|}{ of studies } \\
\hline Characteristic & $\begin{array}{c}\text { Number of } \\
\text { respondents }\end{array}$ & Percentage \\
\hline Gender & 365 & \\
Male & 453 & 44,62 \\
Female & & 55,38 \\
\hline Age group & 655 & 80,07 \\
$18-24$ & 163 & 19,93 \\
$25-51$ & & \\
Area of studies & 273 & 33,37 \\
Technical studies & 116 & 14,18 \\
Biomedicine and health care & 89 & 10,88 \\
Biotechnical studies & 340 & 41,56 \\
Social studies & &
\end{tabular}

In order to establish the basic features of student responses, the analysis was based on descriptive statistics. Methods of inferential statistics were used to determine the statistical significance of differences in student attitudes with reference to their gender, age group and professional area of studies. For this purpose nonparametric Mann-Whitney and Kruskal-Wallis tests were applied. The Mann-Whitney test is a rank-based test. It is an alternative to the independent sample t-test when the assumption of normality is not met or the measurement is made on an ordinal scale. The Kruskal-Wallis test is an alternative to one-way analysis of variance. It is suitable for comparing more than two independent samples.

Statistical significance was set at the level of $p<0,05$. The analysis was carried out using statistical software SPSS and Statistica.

\section{Results}

Within the survey our respondents were asked 16 questions related to the knowledge management project. The emphasis was put on their assessment of the knowledge they acquired during their studies, i.e. on how students evaluate the process of knowledge transfer:

- General assessment of the polytechnic that the respondent is attending (V1);

- Assessment of the quality (content) of the chosen study programme (V2);

- Assessment as to how far study programmes at polytechnics are attuned to labour market needs (V3);

- Assessment of the expertise (knowledge) of teachers teaching at polytechnics (V4);
- Assessment of the skill of polytechnic teachers to transfer knowledge to students (V5);

- Assessment as to how far modern technologies are useful in learning and acquiring knowledge (V6);

- Assessment of the technical (ICT) level of equipment at the polytechnic that the respondent is attending (V7);

- Assessment of the accessibility of teaching materials and literature, i.e. the quality of book supply in polytechnic library in terms of course materials and reference works (V8);

- Assessment of the knowledge acquired while studying at a polytechnic (V9);

- Assessment as to how far the polytechnic is focused on imparting theoretical knowledge (V10);

- Assessment as to how far the polytechnic is focused on imparting practical knowledge (V11);

- Assessment of the need to contract working professionals to teach at polytechnics in order to improve the quality of teaching (V12);

- Assessment of the importance of internship in companies as a tool to help students to expand and affirm the knowledge acquired at a polytechnic (V13);

- Assessment of the usefulness of knowledge and skills acquired at a polytechnic for performing one's future job (V14);

- Assessment of the polytechnic's participation in projects aimed at promoting student mobility and expanding their knowledge (V15);

- Assessment as to how far the polytechnic has contributed to the project of life-long learning (V16).

Student responses were measured on a Likert scale ranged from 1 (the lowest score) to 5 (the highest score). Tab. 2 contains descriptive statistics calculated for the 16 variables listed above.

Table 2 Basic descriptive statistics for research variables

\begin{tabular}{|c|c|c|c|c|}
\hline Variable & Mean & Median & $\begin{array}{c}\text { Standard } \\
\text { deviation }\end{array}$ & $\begin{array}{c}\text { Coefficient } \\
\text { of variation }\end{array}$ \\
\hline V1 & 3,33 & 3,00 & 1,00 & 29,96 \\
V2 & 3,36 & 3,00 & 0,98 & 29,10 \\
V3 & 3,13 & 3,00 & 0,96 & 30,61 \\
V4 & 3,81 & 4,00 & 0,93 & 24,29 \\
V5 & 3,39 & 3,00 & 0,95 & 27,97 \\
V6 & 3,84 & 4,00 & 1,00 & 26,00 \\
V7 & 3,32 & 3,00 & 1,05 & 31,72 \\
V8 & 3,02 & 3,00 & 1,11 & 36,79 \\
V9 & 3,55 & 4,00 & 0,85 & 23,90 \\
V10 & 3,50 & 3,00 & 0,89 & 25,49 \\
V11 & 3,32 & 3,00 & 1,08 & 32,49 \\
V12 & 3,87 & 4,00 & 0,97 & 25,20 \\
V13 & 3,87 & 4,00 & 1,03 & 26,53 \\
V14 & 3,58 & 4,00 & 1,02 & 28,56 \\
V15 & 3,33 & 3,00 & 1,05 & 31,71 \\
V16 & 3,34 & 3,00 & 0,94 & 28,19 \\
\hline
\end{tabular}

Expressed as a mean, the assessments of our respondents were rather uniform; there was not a single variable for which the average score was higher than 4 . Students expressed the highest level of agreement with the need to contract working professionals to teach at polytechnics in order to improve the quality of teaching 
(V12), and with the importance of internship in companies as a tool to help students to expand and affirm the knowledge acquired at a polytechnic (V13). These were followed by the assessment as to how far modern technologies are useful in learning and acquiring knowledge (V6) and the assessment of the expertise (knowledge) of teachers teaching at polytechnics (V4). In this survey, polytechnics in which our respondents were enrolled were scored with the average grade 3,33, whereas the knowledge acquired while studying at a polytechnic was given the average grade of 3,55 . It is interesting to note that the surveyed students believe that polytechnics are more focused on imparting theoretical knowledge rather than practical knowledge. The usefulness of knowledge and skills acquired at a polytechnic for performing one's future job (V14) received the average grade of 3,58 by students. The lowest mean was calculated for the assessment of the accessibility of teaching materials and literature, i.e. the quality of book supply in polytechnic library in terms of course materials and reference works (V8). The respondents also gave a lower score when considering how far study programmes at polytechnics are attuned to labour market needs (V3). For the majority of variables the median has the value 3 , whereas coefficients of variation indicate that all the variables are characterized by relatively high data dispersion.

Table 3 Basic descriptive statistics regarding the gender of students and results of Mann-Whitney test

\begin{tabular}{|c|c|c|c|c|c|c|c|c|}
\hline \multirow{3}{*}{ Variable } & \multicolumn{4}{|c|}{ Gender } & \multicolumn{4}{|c|}{ Mann-Whitney test } \\
\hline & \multicolumn{2}{|c|}{ Male } & \multicolumn{2}{|c|}{ Female } & \multicolumn{2}{|c|}{ Mean rank } & \multirow{2}{*}{$Z$} & \multirow[b]{2}{*}{$p$} \\
\hline & Mean & Median & Mean & Median & Male & Female & & \\
\hline V1 & 3,33 & 3,00 & 3,33 & 3,00 & 406,77 & 406,28 & 0,031 & 0,975 \\
\hline $\mathrm{V} 2$ & 3,33 & 3,00 & 3,39 & 3,00 & 399,18 & 412,42 & $-0,842$ & 0,400 \\
\hline V3 & 3,14 & 3,00 & 3,13 & 3,00 & 408,04 & 402,54 & 0,351 & 0,726 \\
\hline V4 & 3,78 & 4,00 & 3,84 & 4,00 & 399,93 & 410,92 & $-0,703$ & 0,482 \\
\hline V5 & 3,32 & 3,00 & 3,45 & 3,00 & 389,28 & 416,85 & $-1,762$ & 0,078 \\
\hline V6 & 3,83 & 4,00 & 3,85 & 4,00 & 399,84 & 408,26 & $-0,533$ & 0,594 \\
\hline V7 & 3,32 & 3,00 & 3,32 & 3,00 & 404,50 & 407,22 & $-0,172$ & 0,864 \\
\hline V8 & 2,97 & 3,00 & 3,06 & 3,00 & 394,99 & 413,11 & $-1,140$ & 0,254 \\
\hline V9 & 3,50 & 4,00 & 3,59 & 4,00 & 389,47 & 413,12 & $-1,540$ & 0,124 \\
\hline V10 & 3,44 & 3,00 & 3,54 & 4,00 & 387,57 & 412,85 & $-1,632$ & 0,103 \\
\hline V11 & 3,33 & 3,00 & 3,31 & 3,00 & 404,19 & 402,04 & 0,136 & 0,892 \\
\hline V12 & 3,90 & 4,00 & 3,84 & 4,00 & 410,29 & 397,04 & 0,844 & 0,399 \\
\hline V13 & 3,87 & 4,00 & 3,87 & 4,00 & 402,25 & 400,89 & 0,087 & 0,931 \\
\hline V14 & 3,48 & 4,00 & 3,66 & 4,00 & 380,28 & 420,69 & $-2,565$ & 0,010 \\
\hline V15 & 3,23 & 3,00 & 3,41 & 3,00 & 381,85 & 416,71 & $-2,217$ & $\mathbf{0 , 0 2 7}$ \\
\hline V16 & 3,32 & 3,00 & 3,35 & 3,00 & 398,23 & 404,14 & $-0,382$ & 0,702 \\
\hline
\end{tabular}

Table 4 Basic descriptive statistics regarding the age groups and results of Mann-Whitney test

\begin{tabular}{|c|c|c|c|c|c|c|c|c|}
\hline \multirow{3}{*}{ Variable } & \multicolumn{4}{|c|}{ Age group } & \multicolumn{4}{|c|}{ Mann-Whitney test } \\
\hline & \multicolumn{2}{|c|}{$18-24$} & \multicolumn{2}{|c|}{$25-51$} & \multicolumn{2}{|c|}{ Mean rank } & \multirow{2}{*}{$Z$} & \multirow[b]{2}{*}{$p$} \\
\hline & Mean & Median & Mean & Median & $18-24$ & $25-51$ & & \\
\hline V1 & 3,24 & 3,00 & 3,69 & 4,00 & 388,20 & 480,48 & $-4,702$ & $\mathbf{0 , 0 0 0}$ \\
\hline V2 & 3,27 & 3,00 & 3,71 & 4,00 & 387,59 & 482,97 & $-4,865$ & 0,000 \\
\hline V3 & 3,09 & 3,00 & $\mathbf{3 , 3 0}$ & 3,00 & 395,72 & 442,92 & $-2,406$ & 0,016 \\
\hline V4 & 3,74 & 4,00 & 4,11 & 4,00 & 387,73 & 479,76 & $-4,725$ & 0,000 \\
\hline V5 & $\mathbf{3 , 3 2}$ & 3,00 & 3,71 & 4,00 & 386,18 & 478,72 & $-4,740$ & 0,000 \\
\hline V6 & 3,83 & 4,00 & 3,85 & 4,00 & 404,57 & 404,23 & 0,017 & 0,986 \\
\hline V7 & 3,25 & 3,00 & 3,63 & 4,00 & 389,90 & 471,50 & $-4,117$ & 0,000 \\
\hline V8 & 2,94 & 3,00 & 3,35 & 3,00 & 388,99 & 469,44 & $-4,063$ & 0,000 \\
\hline V9 & 3,46 & 4,00 & 3,89 & 4,00 & 380,83 & 490,41 & $-5,716$ & 0,000 \\
\hline V10 & 3,45 & 3,00 & 3,67 & 4,00 & 391,03 & 443,52 & $-2,722$ & 0,006 \\
\hline V11 & 3,25 & 3,00 & 3,60 & 4,00 & 389,11 & 459,44 & $-\mathbf{3 , 5 5 0}$ & 0,000 \\
\hline V12 & 3,86 & 4,00 & 3,90 & 4,00 & 401,72 & 408,17 & $-0,330$ & 0,742 \\
\hline V13 & 3,88 & 4,00 & 3,80 & 4,00 & 406,00 & 383,14 & 1,163 & 0,245 \\
\hline V14 & 3,54 & 4,00 & 3,74 & 4,00 & 393,73 & 438,06 & $-2,253$ & 0,024 \\
\hline V15 & 3,29 & 3,00 & 3,47 & 3,00 & 394,11 & 428,84 & $-1,771$ & 0,077 \\
\hline V16 & 3,28 & 3,00 & 3,57 & 4,00 & 388,14 & 455,11 & $-3,485$ & 0,000 \\
\hline
\end{tabular}

In order to examine the significance of differences in scores by male and female students the Mann-Whitney test was applied (Tab. 3). The results of the MannWhitney test show that only two differences in scores between male and female students are statistically significant: the assessment of the usefulness of knowledge and skills acquired at a polytechnic for performing one's future job (V14) and the assessment of the polytechnic's participation in projects aimed at promoting student mobility and expanding their knowledge (V15). In both of these cases, a higher mean and higher mean rank were calculated for female students.

Tab. 4 contains the basic descriptive statistics, as well as the results that refer to the significance of differences in student scores between two age groups, tested by means of the Mann-Whitney test. In case of the younger versus the older age group, according to Mann-Whitney test the only differences that are not statistically 
significant are the following: assessment as to how far modern technologies are useful in learning and acquiring knowledge (V6), assessment of the need to contract working professionals to teach at polytechnics in order to improve the quality of teaching (V12), assessment of the importance of internship in companies as a tool to help students to expand and affirm the knowledge acquired at a polytechnic (V13), and assessment of the polytechnic's participation in projects aimed at promoting student mobility and expanding their knowledge (V15).
On average, students in older age group gave higher scores to all the items for which significance of differences was confirmed. Furthermore, in all these cases, higher mean ranks were calculated for this group. It can thus be concluded that, in general, older students have a more positive perception of certain aspects of knowledge management at a polytechnic they are attending.

Table 5 Basic descriptive statistics with regard to the area of study

\begin{tabular}{|c|c|c|c|c|c|c|c|c|}
\hline \multirow{3}{*}{ Variable } & \multicolumn{8}{|c|}{ Area of study } \\
\hline & \multicolumn{2}{|c|}{ Technical } & \multicolumn{2}{|c|}{$\begin{array}{l}\text { Biomedicine and health } \\
\text { care }\end{array}$} & \multicolumn{2}{|c|}{ Biotechnical } & \multicolumn{2}{|c|}{ Social } \\
\hline & Mean & Median & Mean & Median & Mean & Median & Mean & Median \\
\hline V1 & 3,20 & 3,00 & 3,22 & 3,00 & 3,93 & 4,00 & 3,32 & 3,00 \\
\hline $\mathrm{V} 2$ & 3,17 & 3,00 & 3,31 & 3,00 & 3,81 & 4,00 & 3,41 & 3,00 \\
\hline V3 & 3,11 & 3,00 & 3,16 & 3,00 & 3,43 & 4,00 & 3,07 & 3,00 \\
\hline V4 & 3,59 & 4,00 & 3,97 & 4,00 & 4,18 & 4,00 & 3,83 & 4,00 \\
\hline V5 & 3,15 & 3,00 & 3,59 & 4,00 & 3,81 & 4,00 & 3,41 & 3,00 \\
\hline V6 & 3,92 & 4,00 & 3,83 & 4,00 & 3,75 & 4,00 & 3,80 & 4,00 \\
\hline V7 & 3,24 & 3,00 & 3,55 & 4,00 & 3,75 & 4,00 & 3,19 & 3,00 \\
\hline V8 & 2,88 & 3,00 & 3,16 & 3,00 & 3,24 & 3,00 & 3,02 & 3,00 \\
\hline V9 & 3,30 & 3,00 & 3,64 & 4,00 & 3,87 & 4,00 & 3,63 & 4,00 \\
\hline V10 & 3,30 & 3,00 & 3,55 & 3,50 & 3,71 & 4,00 & 3,58 & 4,00 \\
\hline V11 & 3,24 & 3,00 & 3,45 & 3,00 & 3,98 & 4,00 & 3,17 & 3,00 \\
\hline V12 & 4,02 & 4,00 & 3,71 & 4,00 & 4,13 & 4,00 & 3,74 & 4,00 \\
\hline V13 & 3,97 & 4,00 & 3,67 & 4,00 & 4,13 & 4,00 & 3,79 & 4,00 \\
\hline V14 & 3,43 & 3,00 & 3,80 & 4,00 & 3,97 & 4,00 & 3,52 & 4,00 \\
\hline V15 & 3,27 & 3,00 & 3,51 & 3,00 & 3,27 & 3,00 & 3,33 & 3,00 \\
\hline V16 & 3,24 & 3,00 & 3,58 & 4,00 & 3,39 & 3,00 & 3,32 & 3,00 \\
\hline
\end{tabular}

Table 6 Results of the Kruskal-Wallis test, including mean ranks

\begin{tabular}{|c|c|c|c|c|c|c|}
\hline \multirow[b]{2}{*}{ Variable } & \multicolumn{4}{|c|}{ Professional area of study (mean rank) } & \multicolumn{2}{|c|}{ Kruskal-Wallis test } \\
\hline & Technical & $\begin{array}{c}\text { Biomedicine and health } \\
\text { care }\end{array}$ & Biotechnical & Social & $H$ & $p$ \\
\hline V1 & 374,18 & 370,16 & 545,75 & 408,54 & 43,105 & $\mathbf{0 , 0 0 0}$ \\
\hline $\mathbf{V 2}$ & 363,51 & 391,08 & 507,19 & 419,92 & 29,813 & $\mathbf{0 , 0 0 0}$ \\
\hline $\mathbf{V 3}$ & 399,33 & 408,83 & 480,50 & 388,50 & 12,275 & 0,006 \\
\hline V4 & 353,94 & 442,66 & 498,11 & 411,04 & 33,550 & $\mathbf{0 , 0 0 0}$ \\
\hline V5 & 345,63 & 448,25 & 507,24 & 409,56 & 42,659 & $\mathbf{0 , 0 0 0}$ \\
\hline V6 & 422,61 & 393,71 & 378,91 & 400,53 & 3,294 & 0,348 \\
\hline V7 & 387,59 & 447,36 & 495,05 & 383,45 & 22,954 & $\mathbf{0 , 0 0 0}$ \\
\hline V8 & 378,04 & 429,07 & 450,67 & 406,23 & 8,822 & 0,032 \\
\hline V9 & 338,18 & 420,63 & 489,67 & 425,09 & 41,963 & $\mathbf{0 , 0 0 0}$ \\
\hline V10 & 355,29 & 410,62 & 450,14 & 422,46 & 19,534 & $\mathbf{0 , 0 0 0}$ \\
\hline V11 & 385,67 & 425,03 & 543,88 & 373,14 & 42,805 & $\mathbf{0 , 0 0 0}$ \\
\hline V12 & 433,49 & 355,15 & 461,25 & 380,14 & 20,029 & 0,000 \\
\hline V13 & 424,38 & 347,88 & 459,51 & 386,64 & 17,111 & 0,001 \\
\hline V14 & 367,80 & 445,27 & 493,80 & 391,71 & 26,322 & $\mathbf{0 , 0 0 0}$ \\
\hline V15 & 387,40 & 439,20 & 384,95 & 403,09 & 4,855 & 0,183 \\
\hline V16 & 378,50 & 458,26 & 405,90 & 399,29 & 10,811 & 0,013 \\
\hline
\end{tabular}

Tab. 5 contains descriptive statistics for the analysed variables with regard to the professional area of study. Almost all the survey items received the most positive assessment by students enrolled in study programmes in biotechnical area. There were only two items for which the lowest average values were calculated for students in this group: assessment as to how far modern technologies are useful in learning and acquiring knowledge (V6), and assessment of the polytechnic's participation in projects aimed at promoting student mobility and expanding their knowledge (V15). In comparison to students in other areas, students of social studies gave the lowest scores to the item asking how far study programmes at polytechnics are attuned to labour market needs (V3), technical (ICT) level of equipment at the polytechnic (V7), and the polytechnic's focus on imparting practical knowledge (V11). Students enrolled in programmes of biomedicine and health care gave the highest average scores when assessing the polytechnic's participation in projects aimed at promoting student mobility and expanding their knowledge (V15), as well as to the contribution of polytechnics to the project of life-long learning (V16). As could be expected, students in technical programmes gave the highest average score in case of the assessment as to 
how far modern technologies are useful in learning and acquiring knowledge (V6). Nevertheless, for students in this particular group, average calculated scores were the lowest in most cases. These results lead to the conclusion that additional efforts should be undertaken, particularly in the domain of technical studies, to align study programmes with employers' needs and to provide teachers with additional training.

Tab. 6 lists the results of testing the significance of differences by means of the Kruskal-Wallis test. According to the Kruskal-Wallis test, there are only two cases, i.e. the assessment as to how far modern technologies are useful in learning and acquiring knowledge (V6), and the assessment of the polytechnic's participation in projects aimed at promoting student mobility and expanding their knowledge (V15), for which no group of students, in terms of their professional area of study, differs significantly from other groups. In general, the highest mean ranks were calculated for students enrolled in study programmes related to the biotechnical area.

In order to establish which groups of students exhibit significant differences in their attitudes related to the knowledge management project at polytechnics, we used the Mann-Whitney test. The results of the Mann-Whitney test indicate that the biggest difference in scores can be found between students enrolled in technical and biotechnical programmes, as well as between students of social and biotechnical studies. The biggest similarities in attitudes were exhibited by students enrolled in programmes of biomedicine and health care and those in the area of social studies.

\section{Conclusion}

By its very nature, higher education has to deal with knowledge management. In contrast to the business sector, however, knowledge management projects have not yet been fully implemented, even in highly developed systems of higher education. The research presented in this paper focused on the analysis of the process of knowledge transfer or knowledge distribution and its success. What provided the impetus for this research was the fact that so far such analyses have not been carried out systematically in the Republic of Croatia. Almost fifteen years after the establishment of first polytechnics in the Republic of Croatia it has not been adequately explored how far they have fulfilled their purpose and objectives.

The results of our study confirmed the first and second hypotheses. However, the third hypothesis was only partially supported. The findings indicate that, in the segment that the research was focused on, knowledge management at Croatian polytechnics has not yet become a reality. Students' satisfaction with the knowledge gained during their studies is not complete, and they believe that polytechnics are focused more on theory than on practice. For this reason, students think that the quality of teaching should be improved by recruiting working professionals who would teach part-time at polytechnics. Another important point for students is internship in companies as a tool to help them expand and affirm the knowledge acquired during their studies. The issue of alignment of study programmes at polytechnics with labour market needs is also highly relevant. Taking into consideration their gender, students have quite homogenous attitudes on the analysed aspects of the knowledge management project. The research has also shown that, for the most part, older students have a more positive perception of the role of polytechnic in the process of knowledge transfer. Given their experience and maturity, older students are more aware of the need for continued education as well as of the possibilities provided by a polytechnic diploma. According to the results of the analysis, students enrolled in study programmes in the biotechnical area gave the highest scores to most of the questions, whereas the lowest average values were calculated for students in technical programmes. The latter indicates that it would be advisable to re-examine the contents and delivery of programmes, especially in the area of technical studies. Apart from providing a direction for eliminating the noticed deficiencies, the results of our research can be the foundation for formulating future development strategies of Croatian polytechnics.

On the basis of available literature, it can be safely asserted that the issue recognized as crucial, and bound to gain in importance, is the one of measuring how successfully a knowledge management project has been implemented. For a realistic assessment and comparability of achievements in such projects it is necessary to develop adequate methodology. This paper is hopefully a contribution to such efforts. In this sense, the results of our research have a wider significance, as the instrument that was developed can be applied in any higher education system. It goes without saying that the questionnaire would have to be additionally validated and supplemented with all the relevant variables.

\section{References}

[1] Gupta, J. N. D.; Sharma, S. K.; Hsu, J. An Overview of Knowledge Management. // Knowledge Management: Concepts, Methodologies, Tools, and Applications / Jennex, M. E. (Ed.). Hershey: Information Science Reference, 2008, pp. 1-22.

[2] Groff, T. R.; Jones, T. P. Introduction to Knowledge Management: KM in Business. Amsterdam: ButterworthHeinemann, 2003.

[3] Tiwana, A. The Knowledge Management Toolkit: Practical Techniques for Building a Knowledge Management System. Upper Saddle River: Prentice Hall, 2000.

[4] Metcalfe, A. S. (Ed.). Knowledge Management and Higher Education: A Critical Analysis. Hershey: Information Science Publishing, 2006. DOI: 10.4018/978-1-59140-509-2

[5] Uriarte, F. A. Jr. Introduction to Knowledge Management. Jakarta: ASEAN Foundation, 2008.

[6] Pan, S. H.; Newell, S.; Huang, J.; Galliers, R.D. Overcoming Knowledge Management Challenges during ERP Implementation: The Need to Integrate and Share Different Types of Knowledge. // Journal of the American Society for Information Science and Technology. 58, 3(2007), pp. 404-419. DOI: 10.1002/asi.20523

[7] Prat, N. A Hierarchical Model for Knowledge Management. // Encyclopaedia of Knowledge Management / Schwartz, D. G. (Ed.). Hershey: Idea Group Reference, 2006, pp. 211-220.

[8] Kidwell, J. J.; Vander Linde, K. M.; Johnson, S. L. Applying Corporate Knowledge Management Practices in Higher Education. // EDUCAUSE Quarterly. 23, 4(2000), pp. 28-33. 
[9] Rowley, J. Is Higher Education Ready for Knowledge Management? // International Journal of Educational Management. 14, 7(2000), pp. 325-333. DOl: $10.1108 / 09513540010378978$

[10] Thitithananon, P.; Klaewthanong, T. Knowledge Management is a Perfect Education Development Tool: Is Thailand's Higher Education Really Ready to Embrace It? // Journal of Knowledge Management Practice. 8, 2(2007), http://www.tlainc.com/articl135.htm

[11] Cranfield, D. J.; Taylor, J. Knowledge Management and Higher Education: A UK Case Study. // The Electronic Journal of Knowledge Management. 6, 2(2008), pp. 85100.

[12] Dagli, G.; Silman, F.; Birol, C. A Qualitative Research Regarding the University Administrators' Capacity to Use of Management Information Tools. // Procedia-Social and Behavioral Sciences. 1, 1(2009), pp. 2480-2490. DOl: 10.1016/j.sbspro.2009.01.438

[13] Chen, M.-Y.; Huang, M.-J.; Cheng, Y.-C. Measuring Knowledge Management Performance Using a Competitive Perspective: An Empirical Study. // Expert Systems with Applications. 36, 4(2009), pp. 8449-8459. DOI: 10.1016/j.eswa.2008.10.067

[14] Penny, K. I.; Dukić, G.; Dukić, D. Knowledge Management: Information and Communication Technologies Usage in Scottish and Croatian Students. // Proceedings of the $32^{\text {nd }}$ International Conference "Information Technology Interfaces" / Cavtat, Dubrovnik, 2010, pp. 385-390.

[15] Laal, M. Knowledge Management in Higher Education. // Procedia Computer Science. 3, (2011), pp. 544-549. DOI: 10.1016/j.procs.2010.12.090

[16] Eftekharzade, S. F.; Mohammadi, B. The Presentation of a Suitable Model for Creating Knowledge Management in Educational Institutes (Higher Education). // ProcediaSocial and Behavioral Sciences. 29, (2011), pp. 1001-1011. DOI: 10.1016/j.sbspro.2011.11.334

\section{Authors' addresses}

Gordana Dukić, Ph.D., Associate Professor Josip Juraj Strossmayer University of Osijek Faculty of Humanities and Social Sciences Department of Information Sciences Lorenza Jägera 9, 31000 Osijek, Croatia E-mail: gdukic@fffos.hr

Goran Kozina, Ph.D., Assistant Professor University North

104. brigade 3, 42000 Varaždin, Croatia

E-mail: goran.kozina@unin.hr

Marin Milković, Ph.D., Associate Professor

University North

104. brigade 3, 42000 Varaždin, Croatia

E-mail: rektor@unin.hr 